\title{
Role of glucokinase and glucose- 6 phosphatase in the nutritional regulation of endogenous glucose production
}

\author{
G Mithieux \\ Unité 197 de I'Inserm, faculté de médecine René-Laënnec, rue Guillaume-Paradin, \\ 69372 Lyon cedex 08, France
}

(Received 29 November 1995; accepted 6 May 1996)

\begin{abstract}
Summary - Two specific enzymes, glucokinase (GK) and glucose-6 phosphatase (Glc6Pase) enable the liver to play a crucial role in glucose homeostasis. The activity of Glc6Pase, which enables the liver to produce glucose, is increased during short-term fasting, in agreement with the enhancement of liver gluconeogenesis. During long-term fasting, Glc6Pase activity is increased in the kidney, which contributes significantly to the glucose supply at that time. On the other hand, GK activity, which allows the liver to utilize glucose, is decreased during fasting. In the fed state, the mechanisms of short-term regulation of the activity of both enzymes takes place during the postprandial period. Liver GlcPase activity is inhibited after refeeding in rats. The inhibition mechanism could involve intracellular metabolites of glutamine and glutamic acid, such as $\alpha$-ketoglutarate, and/or of triglycerides, such as unsaturated fatty acids and acyl-CoA esters. Liver GK activity is activated during the postprandial period. The activation mechanism involves a regulatory protein and the intrahepatic metabolites of fructose, ie fructose1 phosphate and fructose- 6 phosphate.
\end{abstract}

glucokinase / glucose-6 phosphatase / fasting / postprandial metabolism / nutrient

Résumé - Rôle de la glucokinase et de la glucose-6 phosphatase dans la régulation nutritionnelle de la production endogène de glucose. Deux enzymes spécifiques, la glucokinase (GK) et la glucose-6 phosphatase (G/cPase), confèrent au foie un rôle crucial dans l'homéostasie glycémique. La Glc6Pase, qui lui permet de produire du glucose, est augmentée pendant un jeûne court, en accord avec l'augmentation de la gluconéogenèse hépatique. Si le jeûne se prolonge, l'activité Glc6Pase est induite dans le rein, qui contribue alors de façon importante à la production endogène de glucose. En revanche, lactivité de la GK, qui permet au foie de capter le glucose, est fortement réduite au cours du jeûne. À l'état nourri, des mécanismes de régulation à court terme de l'activité des deux

Abbreviations: Glc: glucose; Glc6Pase: glucose-6 phosphatase; Glc6P: glucose-6 phosphate; GK: glucokinase; R: regulatory protein of GK; Fru6P: fructose-6 phosphate; Fru1P: fructose-1 phosphate; $\alpha K G: \alpha$-ketoglutarate. 
enzymes prennent place en situation postprandiale. L'activité de la Glc6Pase hépatique est inhibée après réalimentation chez le rat à jeun, en accord avec l'inhibition de la production de glucose. Le mécanisme biochimique pourrait impliquer des métabolites intracellulaires de la glutamine et de l'acide glutamique, tel que l' $\alpha$-cétoglutarate et/ou des triglycérides, tels que les acides gras insaturés et les acylCoAs. En revanche, l'activité hépatique de la GK est stimulée dans la période postprandiale, en accord avec l'augmentation de l'utilisation du glucose. Le mécanisme implique une protéine régulatrice et les métabolites intrahépatiques du fructose : le fructose-1 phosphate et le fructose 6-phosphate.

glucokinase / glucose-6 phosphatase / jeûne / métabolisme postprandial / nutriment

\section{INTRODUCTION}

The liver plays a crucial role in the regulation of glucose homeostasis since it has the capacity to both produce and utilize glucose (Glc). The expression of two specific enzymes enables the liver to perform this double capacity: glucokinase (GK), responsible for the phosphorylation of Glc in position 6 and therefore for its utilization, and glucose-6 phosphatase (GlcPase), responsible for the dephosphorylation of glucose6 phosphate (Glc6P), thus allowing the liver to release Glc. GK is a monomeric $52 \mathrm{kDa}$ protein, located in the cytosol of the hepatocyte (Andreone et al, 1989). It has been demonstrated that a $62 \mathrm{kDa}$ cytosolic protein is able to bind to GK and to regulate its activity (Van Schaftingen, 1989; Vandercammen and Van Schaftingen, 1990). The Glc6Pasecatalytic subunit is a $40 \mathrm{kDa}$ hydrophobic polypeptide, located in the membrane of the endoplasmic reticulum (Shelly et al, 1993). It has been suggested, but not proven, that a regulatory subunit is associated with the Glc6Pase-catalytic subunit within the membrane (Mithieux et al, 1995). These two enzymes constitute a futile cycle, also called the Glc-Glc6P cycle. Regulatory mechanisms are necessary, so that they do not operate at similar rates concomitantly. Two types of regulatory mechanisms exist. The first type involves variations in the amount of enzyme present and depends on alterations in gene expression. These alterations operate on a time scale of several hours to be complete at the enzyme activity level and occur mainly during fasting. The second regulatory mechanisms occur during the fed state within a few minutes or a few hours at most and occur following a meal. Such a time scale is not compatible with alterations in the amount of protein present. In this case, the regulatory mechanisms induce modifications of the activity of both enzymes.

\section{REGULATION OF GK AND GLC6PASE EXPRESSION DURING FASTING}

The liver GK gene expression is activated by insulin and suppressed by glucagon (Magnusson et al, 1989; Granner and Pilkis, 1990). As a consequence of the decrease in insulinemia, the liver GK activity rapidly diminishes during fasting (Vandercammen and Van Schaftingen, 1993). This is in keeping with the decreased capacity of the liver to utilize Glc under these conditions. It is worth noting that the amount of GK regulatory protein in the liver decreases as well, albeit less markedly (Vandercammen and Van Schaftingen, 1993).

Very little is known about the gene regulation of Glc6Pase, since it has only recently been cloned in murine and human species (Lei et al, 1993; Shelly et al, 1993). It is well known that liver Glc6Pase activity is increased in insulinopenic-diabetic animals, and restored to normal levels through insulin treatment (Ashmore et al, 1954). This suggests that insulin plays a negative control 
role in Glc6Pase gene expression. The timecourse of liver Glc6Pase activity during fasting is complex. It increases during a short fasting period ( 24 and $48 \mathrm{~h}$ in rats), in agreement with the suppressive effect of insulin hypothesized from the experiments in diabetic animals, and with the increased gluconeogenic capacity of the liver under these conditions. On the other hand, we have reported that liver Glc6Pase activity begins to decrease at $48 \mathrm{~h}$ if fasting is prolonged for 72 or $96 \mathrm{~h}$ (Minassian et al, 1994). This peculiar evolution could have an important role in the decrease of liver glucose output known to occur in prolonged starvation (Owen et al, 1969). In this situation, gluconeogenesis is strongly enhanced in the kidney, and may, under these conditions, account for $44 \%$ of total glucose production (Owen et al, 1969). In agreement with the increased participation of the kidney in total glucose production during long-term fasting, kidney Glc6Pase, which progressively increases during the first 2 days of fasting in rats, continues to significantly increase during the longer period of starvation (72 and $96 \mathrm{~h}$ ) (Minassian and Mithieux, 1994). These data emphasize the important role that Glc6Pase could play in triggering gluconeogenesis in both gluconeogenic tissues.

After cloning Glc6Pase cDNA in mice, we amplified a rat Glc6Pase cDNA by reverse transcription-polymerase chain reaction from the total rat liver RNA, using oligonucleotide primers derived from the murine sequence (Mithieux et al, 1996). This cDNA, used as a Northern blot probe, has allowed us to address the question of the role of the abundance of Glc6Pase mRNA in the expression of GlcPase in both tissues during fasting. The time-course for the activity of the Glc6Pase catalytic subunit was similar to the time-course for the Glc6Pase mRNA level in the liver and kidney. In addition, refeeding $48 \mathrm{~h}$ fasted rats for $24 \mathrm{~h}$ promoted normalization of both the abundance of mRNA and its activity in both tissues
(Minassian et al, 1996). These data strongly suggested that the control of Glc6Pase activity during fasting could take place mainly at the pretranslational level.

\section{REGULATION OF GK AND GLC6PASE ACTIVITY IN THE POSTPRANDIAL PERIOD}

The idea that Glc6Pase activity could be inhibited after refeeding was first suggested 10 years ago (Newgard et al, 1984). However, the inhibition has remained controversial because biochemical evidence was still lacking. We have recently produced the first direct evidence that liver Glc6Pase activity is inhibited for a few hours after refeeding in rats (fig 1). The inhibition involved a decrease in the $V_{\max }$ of the enzyme, but it did not involve a decrease in the amount of protein (Minassian et al, 1995). It was observable in liver homogenates and not in microsomes isolated from these homogenates. This suggested that it could be dependent on a nutrient-metabolite present in the homogenates that were lost during the microsome purification procedures.

In agreement with this hypothesis, it was previously reported that Gic6Pase activity is inhibited in vitro by some nutrient-metabolites. It is inhibited by $\alpha$-ketoglutarate ( $\alpha \mathrm{KG}$ ) in the presence of magnesium (Mithieux et al, 1990). This $\alpha K G$-induced inhibition of Glc6Pase takes place within the physiological range of concentration of the effector $(10-50 \mu \mathrm{M})$ (Minassian et al, 1994). $\alpha \mathrm{KG}$ is an important liver cytosolic metabolite of glutamine and glutamic acid (Meister, 1984). The increase in liver cytosolic concentration of $\alpha \mathrm{KG}$ is therefore expected after refeeding since amino acids in the portal vein are actively taken up by the liver. In keeping with a putative regulatory role of $\alpha \mathrm{KG}$ on Glc6Pase activity in the postprandial period, the total liver $\alpha K G$ concentration, which markedly decreases during fasting, rapidly reincreases after refeeding (table I). 
Glc6Pase activity is also inhibited by lipid metabolites. In particular, it is inhibited in vitro by arachidonic acid present in relevant physiological concentrations $(0-50 \mu \mathrm{M})$. Glc6Pase is also inhibited by other unsaturated fatty acids within the same range of concentration (Mithieux et al, 1993). It has also been reported that Glc6Pase is inhibited by fatty acyl-CoA esters in a dose-dependent manner at low concentrations $(0-20$ $\mu \mathrm{M})$. This effect is dependent on the acylchain length. The longer the chain length, the higher the inhibitory effect (Mithieux and Zitoun, 1996). It would be interesting to address the question of the putative role of fatty acids and/or acyl-CoA esters on Glc6Pase in vivo. The concentration of fatty acyl-CoA esters is increased in the liver during fasting (Woldegiorgis et al, 1985). Fasting is a situation where Glc6Pase should be fully active to allow the liver to release glucose. This seems to be in disagreement with a physiological inhibitory role of fatty acyl-CoA esters on Glc6Pase activity. However, the crucial factor should be the actual amount of the effector present within the membrane, since such amphipatic molecules as unsaturated fatty acids or acylCoA esters are expected to accumulate in the lipophilic domains of membranes (Mithieux et al, 1993). The question of the physiological concentration of fatty acids and acyl-CoA esters within intracellular membranes is unfortunately impossible to address reliably since it would require the prior purification of membranes from homogenized livers and it is well known that strong activation of phospholipases and acyl-CoA

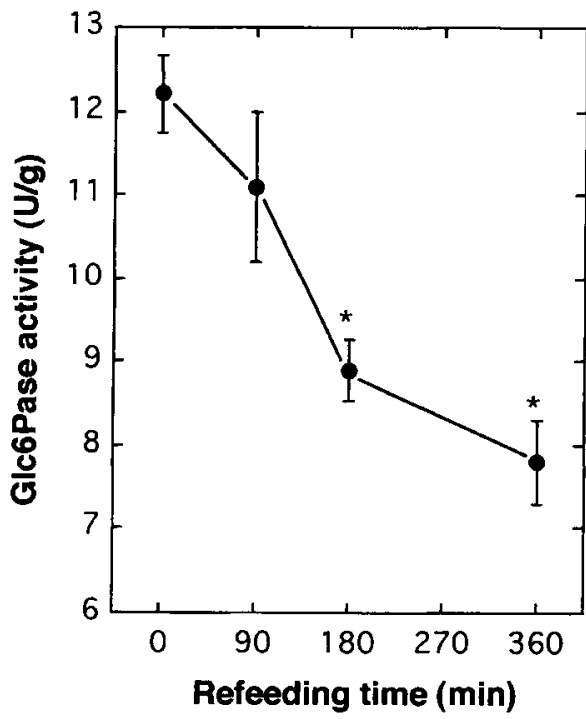

Fig 1. Effect of refeeding on liver Glc6Pase activity in $48 \mathrm{~h}$ fasted rats. Glc6Pase was determined as described previously (Minassian et al, 1995). The data are expressed as $\mathrm{U} / \mathrm{g}$ wet liver. One unit of Glc6Pase converts 1 $\mu \mathrm{mol}$ of Glc6P per min at $37{ }^{\circ} \mathrm{C}$ under assay conditions. The results are expressed as means \pm SEM from six animals at each refeeding time. Statistical analysis was performed using Fisher's test. * Significantly different from fasted value, $P<0.01$.

Table I. Effect of fasting and refeeding on liver $\alpha$-ketoglutarate $(\alpha K G)$ concentration in rats.

\begin{tabular}{|c|c|c|c|c|}
\hline \multirow[t]{2}{*}{ Animals } & \multirow[t]{2}{*}{ Fed } & \multicolumn{2}{|c|}{ Fasted for } & \multirow{2}{*}{$\begin{array}{l}48 h \text { fasted } \\
\text { refed for } 3 h\end{array}$} \\
\hline & & $24 h$ & $48 h$ & \\
\hline$\alpha K G(n m o l / g)$ & $46 \pm 3(13)$ & $20 \pm 1(14)^{a}$ & $14 \pm 2(8)^{\mathbf{a}}$ & $37 \pm 5(6)^{b}$ \\
\hline
\end{tabular}


hydrolases occurs very rapidly during the homogenization of tissues, resulting in a dramatic release of fatty acids from phospholipids and CoA esters.

$A$ very interesting observation is that the mechanism by which GK is inhibited by its regulator $(R)$ is dependent on intracellular metabolites of a nutrient: fructose. $R$ exhibits a binding site for fructose -6 phosphate (Fru6P). In the presence of Fru6P, R-Fru6P is able to bind to GK to form a GK-R-Fru6P complex in which GK is not active (Vandercammen and Van Schaftingen, 1990). The effect is dependent on both the concentration of Fru6P and of R (Van Schaftingen, 1989). Fructose-1 phosphate (Fru1P) is able to displace Fru6P from $R$ in a dose-dependent manner (Van Schaftingen, 1989). RFru1P is then no longer capable of interacting with GK, which therefore becomes fully active (Vandercammen and Van Schaftingen, 1990). Noteworthy, the concentration of hepatic Fru6P never varies to a large extent due to its role as metabolic intermediate in glycolysis/gluconeogenesis. On the other hand, the liver concentration of Fru1P is strongly dependent upon fructose feeding. The mechanism by which GK is activated during the postprandial period can be summarized as follows: in the postabsorptive state, fructosemia is nearly zero and the intracellular concentration of Fru1P is very low. GK is expected to be only poorly active in this situation because of the inhibitory effect of R-Fru6P. After feeding, fructosemia increases in the portal vein. Fructose is taken up by the liver and the intrahepatic concentration of Fru1P increases as a result of phosphofructokinase activity. Fru1P thus liberates GK from the inhibition by $R$. GK is also activated due to the elevated concentration of its substrate. In agreement with the important role of this mechanism in vivo, Van Schaftingen and Vandercammen (1989) demonstrated that glucose phosphorylation in isolated hepatocytes, at glucose concentrations close to $10 \mathrm{mM}$, is doubled in the presence of fructose at relevant postprandial concentrations $(0.2 \mathrm{mM})$.

\section{CONCLUSION}

An hypothetical mechanism of regulation of the Glc-Glc6P cycle by nutrient metabolites in the postprandial period is proposed. Nutrients in the portal vein could act in cooperation to shift the liver metabolism from glucose production to glucose utilization (fig 2). The role of hexoses could then be to activate glucose utilization by the liver: fructose upon the deinhibition of GK by means of Fru1P, glucose upon stimulation of GK by substrate effect. Amino acids, particularly glutamine and glutamic acid, by means of $\alpha \mathrm{KG}$, and triglycerides, by means of unsaturated fatty acids and acyl-CoA esters, could inhibit Glc6Pase and hepatic glucose production. It should be emphasized that insulin could potentiate this concerted action in several ways. By activating acetyl-CoA carboxylase, it increases the intrahepatic concentration of malonyl-CoA, which is the physiological inhibitor of carnitine palmitoyl-transferase 1 (the obligatory transporter of acyl-CoA ester into mitochondrion, in which they are oxidized). This could result in the enhancement

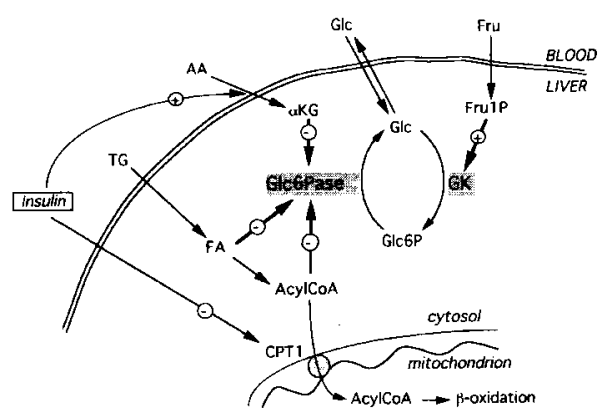

Fig 2. Hypothetical mechanism of Glc-Glc6P cycle regulation by nutrient metabolites. TG: triglycerides; AA: amino acids; CPT1: carnitine palmitoyl-transferase 1; FA: fatty acids; other abbreviations as on bottom of title page. 
of the concentration of acyl-CoA ester in the cytoplasmic compartment. It is also well established that insulin stimulates the transport of amino acids into the liver.

\section{ACKNOWLEDGMENTS}

The author wishes to acknowledge the persons who participated in the work on Glc6Pase: A Ajzannay, JC Bordet, N Bruni, N Daniele, C Minassian, C Zitoun, S Tarpin and is grateful to M Beylot, M Laville, $\mathrm{H}$ Vidal, JP Riou and $\mathrm{E}$ Van Schaftingen for numerous helpful discussions. Our work was financially supported by the Institut national de la santé et de la recherche médicale, the Association française contre les myopathies, the Institut électricité-santé, the companies Lilly-France and LIPHALyonnaise Industrielle Pharmaceutique.

\section{REFERENCES}

Andreone TL, Printz RL, Pilkis SJ, Magnusson MA, Granner DK (1989) The amino-acid sequence of rat liver glucokinase deduced from cloned cDNA. J Biol Chem 264, 363-369

Ashmore J, Hastings AB, Nesbett FB (1954) The effect of diabetes and fasting on liver glucose- 6 phosphatase. Proc Natl Acad Sci USA 40, 673-678

Granner DK, Pilkis SJ (1990) The genes of hepatic glucose metabolism. J Biol Chem 265, 10173-10176

Lei KJ, Shelly LL, Pan CJ, Sidbury JB, Chou JY (1993) Mutations in the glucose- 6 phosphatase gene that cause glycogen storage disease type 1a. Science $262,580-583$

Magnusson MA, Andreone TL, Printz RL, Koch S, Granner DK (1989) Rat glucokinase gene: structure and regulation by insulin. Proc Natl Acad Sci USA 86, 4838-4842

Meister A (1984) Glutamine Metabolism in Mammalian Tissues (D Haüssinger, $H$ Sies, eds), Springer-Verlag, Berlin, 3-15

Minassian C, Mithieux G (1994) Differential time-course of liver and kidney glucose-6 phosphatase activity during fasting in rats. Comp Biochem Physio/ 109B, 99-104

Minassian C, Ajzannay A, Riou JP, Mithieux G (1994) Investigation of the mechanism of glycogen rebound in the liver of $72 \mathrm{~h}$-fasted rats. $J$ Biol Chem 269 , 16585-16588

Minassian C, Daniele N, Bordet JC, Zitoun C, Mithieux $G$ (1995) Liver glucose-6 phosphatase activity is inhibited by refeeding in rats. J Nutr $125,2727-2732$
Minassian C, Zitoun C, Mithieux G (1996) Differential time-course of liver and kidney glucose-6 phosphatase activity during long-term fasting in rat correlates with differential time-course of messenger RNA level. Mol Cell Biochem 155, 37-41

Mithieux G, Zitoun C (1996) Mechanisms by which fattyacyl-CoA esters inhibit or activate glucose- 6 phosphatase in intact and detergent-treated rat liver microsomes. Eur J Biochem 235, 799-803

Mithieux G, Vega F, Riou JP (1990) The liver glucose-6 phosphatase of intact microsomes is inhibited and displays sigmoid kinetics in the presence of $\alpha$-ketoglutarate-magnesium and oxaloacetate-magnesium chelates. J Biol Chem 265, 20364-20368

Mithieux G, Bordet JC, Minassian C, Ajzannay A, Mercier I, Riou JP (1993) Characteristics and specificity of the inhibition of liver glucose- 6 phosphatase by arachidonic acid. Lesser inhibitability of the enzyme of diabetic rats. Eur J Biochem 213, 461-466

Mithieux G, Ajzannay A, Minassian C (1995) Identification of membrane-bound phosphoglucomutase and glucose- 6 phosphatase by ${ }^{32} \mathrm{P}$-labelling of rat liver microsomal membrane proteins with $32 \mathrm{P}$-glucose- 6 phosphate. J Biochem 117, 908-914

Mithieux G, Vidal H, Zitoun C, Bruni N, Daniele N, Minassian C (1996) Glucose-6 phosphatase mRNA and activity are increased to the same extent in kidney and liver of diabetic rats. Diabetes (in press)

Newgard CB, Foster DW, McGarry JD (1984) Evidence for suppression of hepatic glucose- 6 phosphatase with carbohydrate feeding. Diabetes 33, 192-195

Owen DE, Felig P, Morgan AP, Wahren J, Cahill GF (1969) Liver and kidney metabolism during longterm starvation. J Clin Invest 48, 574-583

Shelly LL, Lei KJ, Pan CJ, Sakata SF, Ruppert S, Schutz $G$, Chou JY (1993) Isolation of the gene for murine glucose- 6 phosphatase, the enzyme deficient in glycogen storage disease type $1 \mathrm{~A}$. J Biol Chem 268 , 21482-21485

Vandercammen A, Van Schaftingen E (1990) The mechanism by which rat liver glucokinase is inhibited by the regulatory protein. Eur J Biochem 191, 483-489

Vandercammen A, Van Schaftingen E (1993) Species and tissue distribution of the regulatory protein of glucokinase. Biochem J 294, 551-556

Van Schaftingen E (1989) A protein from rat liver confers to glucokinase the property of being antagonistically regulated by fructose- 6 phosphate and fructose- 1 phosphate. Eur J Biochem 179, 179-184

Van Schaftingen E, Vandercammen A (1989) Stimulation of glucose phosphorylation by fructose in isolated hepatocytes. Eur J Biochem 179, 173-177

Woldegiorgis G, Spennetta T, Corkey BE, Williamson JR, Schrago $E$ (1985) Extraction of tissue long-chain acyl-CoA esters and measurement by reverse-phase high-performance liquid chromatography. Anal Biochem 150, 8-12 